\title{
SYMBOLIC CAPITAL AS A RESOURCE OF PROMOTION OF PROVINCIAL CITIES: AN ANALYSIS OF PLACE BRANDING STRATEGIES OF URAL URBAN DESTINATIONS
}

\author{
Alexey Britvin \\ Lecturer, Chair of Integrated Marketing Communications and Branding \\ Ural Federal University, Russia \\ alexey.britvin@urfu.ru

\section{Irina Britvina} \\ Professor, Chair of Integrated Marketing Communications and Branding \\ Ural Federal University, Russia \\ irina.britvina@urfu.ru
}

\section{Liudmila Starostova}

Associate Professor, Chair of Integrated Marketing Communications and Branding

Ural Federal University, Russia

Head of Development Department of Boris Yeltsin's Museum

Yekaterinburg, Russia

starostova5@mail.ru

\section{Marc Compte-Pujol}

Lecturer, Department of Communication

University of Vic - Central University of Catalonia, Spain

marc.compte@uvic.cat

\begin{abstract}
The article analyzes the concept of the symbolic capital of a territory and substantiates the importance of its identification and its use for the promotion of three provincial cities in Russia: Shadrinsk, Chebarkul, and Chelyabinsk. Based on the approach of symbolic interactionism and the use of semiotic analysis, the authors of the article propose to group the resources of the symbolic capital of a territory in three ways. They use signs or symbols, images of the territory, and archetypes. The capital of a provincial city can be perceived symbolically both by external (investors and tourists) and internal (local residents) audiences. They serve as a means of shaping the image and reputation of the place. Both P. Bourdieu's concept of symbolic capital and V. Radaev's classification for different types of capital allow us to give examples of conversion from the cultural
\end{abstract}


resources of a territory into symbolic capital. The analysis of the communication resonance of a particular mega event (the meteorite fall on the territory of the Southern Urals in 2013) and the study of cultural heritage of the provincial Russian city of Shadrinsk make it possible to identify the actual directions for converting the intangible resources of cities into their symbolic capital.

Keywords: city branding, folklore, intangible resources, provincial city, symbolic capital

\section{INTRODUCTION}

Until the second half of the nineteenth century, place marketing relied mainly on material resources. Later, with the development of the means of communication and the changing world economy, symbolic resources became widely used (Kotler \& Haider \& Rein 1993). At the beginning of the twenty-first century, place branding technologies were extensively developed in Russia. Municipalities recognized the need for a communication strategy in the formulation of an investment policy that would comprehensively approach the problem of attracting investment resources, as well as in the course of municipal, regional and federal election campaigns. Meanwhile, the competition for attracting investors and tourists as well as residents was extremely high. Some researchers (Vizgalov 2011, 2015; Dubeykovskiy 2017) have described the experience of place branding in a wide range of Russian cities - both metropolitan (Moscow, St. Petersburg, Kazan) and provincial ones (Veliky Ustyug, Myshkin, Uryupinsk). Researchers have noted that provincial cities are in a more vulnerable position in the competition for residents, investors, and tourists. As a rule, these are small towns (with a population of up to 50,000 inhabitants) and medium-sized cities (up to 100,000 inhabitants).

Due to the symbolic nature of social relations, symbols, such as identification marks and conditional codes, are used as an integral part of communication. A system of local symbols that is intelligible to investors increases the competitiveness of the place. The recognition, fame, and attractiveness of a territory can then be converted into symbolic capital. This can become an effective intangible asset, which increases the overall capitalization of the territory (Britvin \& Britvina \& Starostova 2016). Despite that provincial cities have significant differences from capitals; they still have their own urban identity. Certain target audiences may evaluate some of their non-capital characteristics as advantages. In addition, the provincial Russian cities have a significant cultural heritage that can be converted into symbolic capital. Meanwhile, the communication activity of municipalities in provincial cities is usually aimed at informing internal target audiences about the actions of local authorities 
and ongoing everyday events. However, the promotion of a place has not yet become a systemic practice of the city authorities.

\section{LITERATURE REVIEW}

A number of works by philosophers, sociologists, and culturologists, such as R. Guenon (1962), M. Eliade (1987 [1965]), P. Berger \& T. Luckmann (1966), H. Blumer (1969), J. Baudrillard (1976, 1988), A. Losev (1994), J. Lotman (2010 [2000]), and many others are devoted to the study of symbolic relations. The concept of symbolic interactionism appeared in the late 1930s. The concept of symbolic exchange in social relations, developed by J. Baudrillard in the 1970s (Baudrillard 1976), was supplemented with the concept of symbolic capital by P. Bourdieu in the 1980s (1980, 2002).

V. Radaev defines capital as "an accumulated economic resource that is included in the processes of reproduction and expansion of value through the cross conversion of various forms" (Radaev 2002). Based on the general approach and classification principles given by P. Bourdieu, V. Radaev identifies the main forms of capital as follows: economic, physical, cultural, human, social, administrative, political, and symbolic. Each of them, in accordance with the concept of P. Bourdieu, exists in three states: objectified, incorporated, and institutionalized.

Modern researchers apply the concept of symbolic capital to the study of the practices and capabilities of social actors that use it as a resource to achieve a certain social status. For example, T. Basaran and Ch. Olsson consider international global practices of social networking as a kind of symbolic resource (Basaran \& Olsson 2018). H. Bauder, C.-A. Hannan and O. Lujan analyze the international mobility of academic researchers as a means of strengthening their symbolic resources (Bauder \& Hannan \& Lujan 2017). O. Locock, A.-M. Boylan, R. Snow and S. Staniszewska study the use of symbolic capital by patients in the public health service (Locock et al. 2017). S. Yamak, A. Ergur, M. Özbilgin and O.N. Alakavuklar describe the practice of converting symbolic resources into symbolic capital by various gender groups under the dominance of corporate elites and patriarchy in Turkish families (Yamak et al. 2016).

Marketing professionals also draw attention to the symbolic resources of a territory. The most famous publications belong to S. Anholt, F. Kotler et al., T. Gad, A. Pankrukhin, D. Vizgalov, T. Sachuk, A. Stas, and V. Dubeykovsky. R. Hibbitt analyzes the symbolic resource of the city of Bruges through the contribution of the poetics of symbolism to its cultural space (Hibbitt 2017). As a rule, the symbolic capital of a territory is understood as heritage (Michelson 
\& Paadam 2016). In fact, academically, heritage can be defined as the DNA of places (Mihailovich 2006: 231), or at least as one of the main determinants of the individual character of places (Ashworth 1994: 19). Thus, it is a concept deeply connected to the formation of place identity (Curtin \& Gaither 2007: 178; Gómez Schettini \& Troncoso 2011: 199; Graham \& Howard 2008; Morgan \& Huertas 2011: 153; Peterková 2003: 3; Palmer 1999: 315; San Eugenio Vela 2013: 189; San Eugenio Vela \& Xifra 2014: 89; Smith 2006: 301; Skinner 2008: 918), which is in turn the essence from which any place brand should be built (Aitken \& Campelo 2011: 913; Anholt 2009: 6; Aronczyk 2008: 42; Calvento \& Colombo 2009: 265; Hall 2010: 70; Hildreth 2010: 28; Kavaratzis 2004: 63-64). In this sense, some place researchers also use the term "territorial capital", including in it tangible and symbolic resources (Grignoli \& Mancini 2016).

D. Vizgalov attributes to the symbolic capital of the city its accumulated collective memory, traditions, ideas, and meanings (Vizgalov 2011). M. Vandyshev, N. Veselkova and E. Priamikova understand the symbolic capital of a territory as objectified and structured ideas about the values of the elements that organize the urban space, which form the basis for place recognition and sustainable identification (Vandyshev \& Veselkova \& Priamikova 2013). D. Zamiatin, N. Zamiatina, and I. Mitin (2008) note that symbolic capital can be considered as a link between an insight into the space itself and the role of these insights in the social and economic development of territories.

A territory (country, region, city) as a geographic object has different material resources, on the operation of which the welfare of residents and non-residents depends. A territory is considered as a combination of economic, social, and cultural capitals. Economic capital is objectified in the means of production, directly converted into money, and institutionalized in the form of ownership. Cultural capital, which is a combination of historical heritage and educational systems, is institutionalized in local traditions and institutions. Social capital is a system of public relations and certain social obligations that facilitate the "social lift" - the possibility for self-realization of the residents and non-residents of the territory.

P. Bourdieu believes that capital objectified in material objects and means can be transferred both materially (as economic capital) and symbolically, when it is invested as a means of struggle in the fields of cultural production (artistic, scientific, etc.) and beyond their borders, in the fields where social forces operate. That is, symbolic capital is "a capital in any form, perceived symbolically in connection with some knowledge or, more accurately, recognition or nonrecognition" (Bourdieu 2002). Bourdieu also emphasizes that symbolic capital adds value to the object of capitalization. 
According to V. Radaev (2002), symbolic capital means a person's ability to produce opinions. Thus, the incorporated state of the territory's symbolic capital is: 1) the availability of knowledge of capitals; and 2) the right to interpret the value of any capital. The institutionalized state is the recognition (acknowledgment) of the value of the capital.

D. Vizgalov notes that symbolic capital affects the urban environment mental images, urban space, and infrastructure (Vizgalov 2011). Moreover, Vizgalov identifies urban identity with the symbolic (semantic) capital of the city, and builds up a logical sequence: symbolic capital - images of the city brand of the city - city image - city reputation (ibid.). Thus, the symbolic capital of a territory is the resources that, in the process of communication, are being formalized in public or personal opinions (judgments, beliefs, expectations) about their usefulness, attractiveness, and relevance. That is to say, the brand, image, and reputation can be considered as a kind of symbolic capital of a territory. In the framework of this article we are talking about the influence of the symbolic capital on whether the territory is trusted or distrusted by the residents and non-residents.

By extrapolating the concept of symbolic capital to the level of territorial communities, we discover symbolic capital both in the aggregate of archetypes and cultural symbols inherent in the territory, and in the multiplicity of complex associative links that form a figurative perception of the territory. By understanding the territory as a social system, we can bestow on it such categories as fame, recognition, and prestige. The symbolic nature of any kind of capital presupposes the transfer of the values formed by the perception of the object to the object itself.

In place promotion technologies are based on the translation of images and related values, and the main role is played by such subjective categories as impressions, associations, and representations. In this logic, any phenomenon is subject to actualization in order to convey to the target audience the meaning of any proposal coming from the territory.

Using E.H. Schein's approach, which distinguishes such levels of culture as artifacts (objects that have both physical characteristics and symbolic content), proclaimed values (sayings and actions that reflect certain common beliefs), and basic representations (obvious to the community's "deep" representations that cannot be varied) (Schein 2004 [1985]), we suggest we group the types of the symbolic capital of a territory in the following way:

- Signs or symbols as signifiers: objects (material) and traditions that are markers of the territory and represent visible forms of the reflection of territorial values (artifacts); 
- Images of the territory - indirect representations based on statements and actions in relation to the territory (proclaimed values);

- Archetypes - universal images (symbols), "keys" for reading the territory (basic representations).

Thus, the objectified state of the symbolic capital can be an unlimitedly replenished resource for the promotion of the territory. That is, the territory is not only a geographical space, but also a mental one - perceived and imagined (Zamiatin 2013).

In such a space, the following variety of symbolically perceivable objects can be used as landmarks:

- Geographical names (toponyms);

- Unique natural objects, landscapes;

- Places of interest;

- Architecture;

- Monuments (memorials);

- Historical events;

- Myths;

- Goods and services;

- Artistic images (literary, cinematographic);

- Geniuses of the place;

- Declarations ("Uryupinsk is the capital of a Russian province"; "Copenhagen is an open city").

The list is not comprehensive and should not be considered as a complete classification. The task of place branding is to transform the above-mentioned resources into media images and ensure their translation into the target media space (Zamiatin 2013). We can consider these resources as the symbolic capital of a territory in the case of a certain identification of their value - symbolic utility.

\section{METHODOLOGY}

The article proposes the case study methodology based on the academic knowledge about the concept of symbolic capital (Bourdieu 1980, 2002). With this study, the authors seek to analyze different contemporary communication strategies of three Russian provincial cities in the Urals - Shadrinsk, Chebarkul, and Chelyabinsk - in order to check to what degree symbolic capital is being used, as well as to discuss how it could be improved, if needed, by the city authorities in a professional way. 
To study the prospects and practices of the capitalization of the symbolic capital of those cities, we have used the following methods of collecting and analyzing information: an analysis of texts gathered from interviews with experts and media analysts; an analysis of territorial media resources and regional mass media; a study of historical and folkloric printed sources about the territory; and a narrative analysis of urban symbols and attractions. We have also included an observation made while doing sightseeing in the cities, a comparative analysis of the cities, and an image analysis of several territories. The analysis of the material was conducted on the principle of data mining (extraction and interpretation of previously unknown non-standard data to offer an optimal solution), in order to build hypotheses on the basis of the identified real or potential symbolic capital that can be proposed for the investment territory.

In short, the authors propose some knowledge transfer from the academy to the professional world, which could be interesting not only for managers of provincial Russian cities, but for any professional manager who may work with place branding strategies anywhere in the constantly changing world.

As a limitation, we state that this article cannot be taken as a representative study, but only as a sample of trends.

\section{RESULTS}

After studying three Russian provincial cities - Chebarkul, Chelyabinsk, and Shadrinsk - we identified their symbolic resources and their possible capitalization. A separate study was devoted to each of the following symbolic territorial resources.

On February 15, 2013, there was a meteorite fall in the Chelyabinsk region (Russia) near the city of Chebarkul and Lake Chebarkul. Fortunately, after the meteorite had fallen on the Chelyabinsk region, the territory was not reprogrammed: neither Chelyabinsk nor Chebarkul became symbols of a new meaning, such as Chernobyl in Ukraine or Fukushima in Japan, and the totality of the sign spaces of the Southern Urals remained unchanged. In our opinion, this implies the possibility of integrating the fact of meteorite fall into the two dominant semiotic categories of the Southern Urals - industry and nature. The explosion of a meteorite over Chelyabinsk, which frightened the inhabitants and caused minor disruptions, in general means a threat, a danger. And the fall of the meteorite into Lake Chebarkul in the city of Chebarkul, but in a deserted place, can be treated as a miracle, a gift (a wonderful landing). Understanding this feature gave the cities of Chelyabinsk and Chebarkul the prospect of their joint promotion without competition between them. There are several really and 
potentially dangerous manufacturing enterprises in the Chelyabinsk region, and the image of a city that has escaped a cosmic catastrophe has chances to become a symbol of changes in the thinking of modern humanity. We state that the government officials and authorities of the city and region of Chelyabinsk either did not find the event that attracted world attention to be a promising symbolic resource, or could not transform it into the right to legitimate the interpretation of global security problems, which would help to solve acute environmental problems in the region. Unfortunately, the inertia of industrial thinking, which has stepped back from the oncoming consequences of industrial civilization, has worked out in this case. At the same time, we believe that for the city of Chebarkul the symbolic capitalization of the fall of the meteorite has remained topical and supports the creation of a brand that distinguishes Lake Chebarkul from other lakes in the Southern Urals. The town which is paradoxically known as a Ural resort, and a military training ground as well, was able to integrate the newest narrative - a meteorite story - into its identity.

Now let us turn to the analysis of the possibility of transforming the cultural capital into symbolic capital on the example of the city of Shadrinsk in the Kurgan region, part of the Urals Federal District of Russia. Shadrinsk is a city in the Kurgan region with the population of about 77,000 people. Among the six regions of the district, the Kurgan region has the least economic capital. Let us dwell in more detail on the examples of the capitalization of the city of Shadrinsk by identifying the phenomena of cultural and historical heritage, which previously had no symbolic significance in the public opinion.

A vivid example of the construction of the symbolic capital of a provincial city by moving from Russian folk art to the modern context is the tales recorded by local historian Alexander Zyryanov in the Urals in the middle of the nineteenth century. These tales became widely known thanks to Alexander Afanasyev, who performed the first complete edition of Russian folk tales. A. Afanasyev, among others, published works of verbal folk art from the manuscript of Zyryanov. The manuscript contained 17 fairy tales. All of them were published by A. Afanasyev in the famous collections Russian Folk Tales $(1856,1861)$ and Russian Folk Legends (1860). The fairy tale "The Frog Princess" was published there as well. Finnish folklorist Antti Aarne, who in 1910 created the index of fairy tales, examined all the fabulous texts collected by that time, which were concentrated in several European collections. The collection compiled by A. Afanasyev was the largest of all at that time. Multiple refinements of the index of fairy tales have turned Aarne's work into a universal international catalog of fairy-tale subjects, without addressing to which no researcher of verbal narrative traditions can do. 
Having analyzed the text of the fairy tale "The Frog Princess", heard and recorded near Shadrinsk, we concluded it was unique, which makes it possible to draw attention to the possibility of transforming this cultural capital into the symbolic capital of the territory.

The fairy tale is based on two plots: the princess-frog and the disappeared wife. The first story is the following: three princes go to look for future wives in the direction of their lit arrows; the youngest prince finds a frog in the swamp, she becomes his wife, performs the king's orders best of all (sews, weaves, bakes, dances) and turns into a princess; the husband burns her frog skin, after which the princess disappears. The second story tells about a husband looking for his wife who has disappeared, and magic objects or animals help him. The Shadrinsk text is the most solid, logical, compact, and informative of all the accessible fairy-tale texts about the princess-frog. "The Frog Princess" is a traditional contamination of plot types. Numerous variants of such a fairy tale are known: European, Turkish, Indian, Arabic, as well as those recorded from Americans of European and African descent in Spanish, Portuguese, and French; also 36 Russian, 15 Ukrainian, and 6 Belarusian variants. Even A. Afanasyev's collection contains three texts, including the text from Shadrinsk. But the uniqueness of the Shadrinsk text, on the one hand, and the world fame of the plot, on the other, make it possible to offer a fairy-tale character as a territorial identifier that has been included in the context of Russian and world written culture for more than 150 years, and in the context of verbal folk culture for thousands of years. Well-known images have a high communicative potential, acting as symbols of a territory; they can represent the territory where it was not previously represented. "The Frog Princess" carries the charm of verbal folk art - imagery, entertainment, enlightenment - and has not lost its educational value either - it translates the ideas of gender behavior stereotypes and the beauty of folk culture. We suggested using this fairy-tale character as a tool for city promotion.

Shadrinsk has some other cultural resources that are not fully converted into its symbolic capital. As an example of the influence of an artistic text on the formation of the identity of Shadrinsk, we can cite the story of the Shadrinskiy goose. The satirical novel "Shadrinskiy Goose" (1936), published in Russia in mass editions, was the first widely known literary work about Shadrinsk and its environs, initiating the process of local mythmaking, which resulted in a reassessment of the symbolic "value" of the city name. In the Great Soviet Encyclopedia the Ural breed of domesticated gray northern geese received a parallel naming - Shadrinskaya (GSE 1977, 1978).

A pseudo-historical anecdote about the travel of geese to St. Petersburg during the reign of Empress Catherine the Great allowed to expand the value 
interpretation of the image of the goose: on the one hand, the attractiveness of the local geese's commercial qualities was accentuated; on the other, a metaphor for Shadrinsk people appeared. The phrase "Shadrinsky goose", which has received an emotional content, was based on the famous Russian idiom "What a goose!" used in the novel. In the early 1990s, the image of the goose was paraphrased, and thereafter it became a symbolic expression of the specific local world outlook - "Shadrinskiy". Among the young people of the city of Shadrinsk, a double-headed goose (reminiscent of the state coat of arms of Russia) became a kind of evidence of the affirmation of the image of the goose as a symbol of the city. The choice of a goose as an official figure in the official symbolism of the Shadrinsk region is also a matter-of-course: the goose not only literally portrays the famous breed of domestic birds, but also allegorically transmits the image of the defender: a proud and courageous bird, faithful to its family and always ready to protect it. Several times an interregional poultry fair has been held under the name "Shadrinskiy goose". The evolution of the sculpted image of the goose is also indicative: a goose peeping out of a basket when bargaining at the market place (2007) and a goose with a balalaika as an expression of a vivid emotion (2014). A ceramic goose whistle has become one of the most popular Shadrinsk souvenirs. The image of a goose now continues to develop in contrast to the image of a marten, which has been on the city's official coat of arms since 1712, and whose Siberian origin is currently not in demand in Shadrinsk's "trans-Ural" identity.

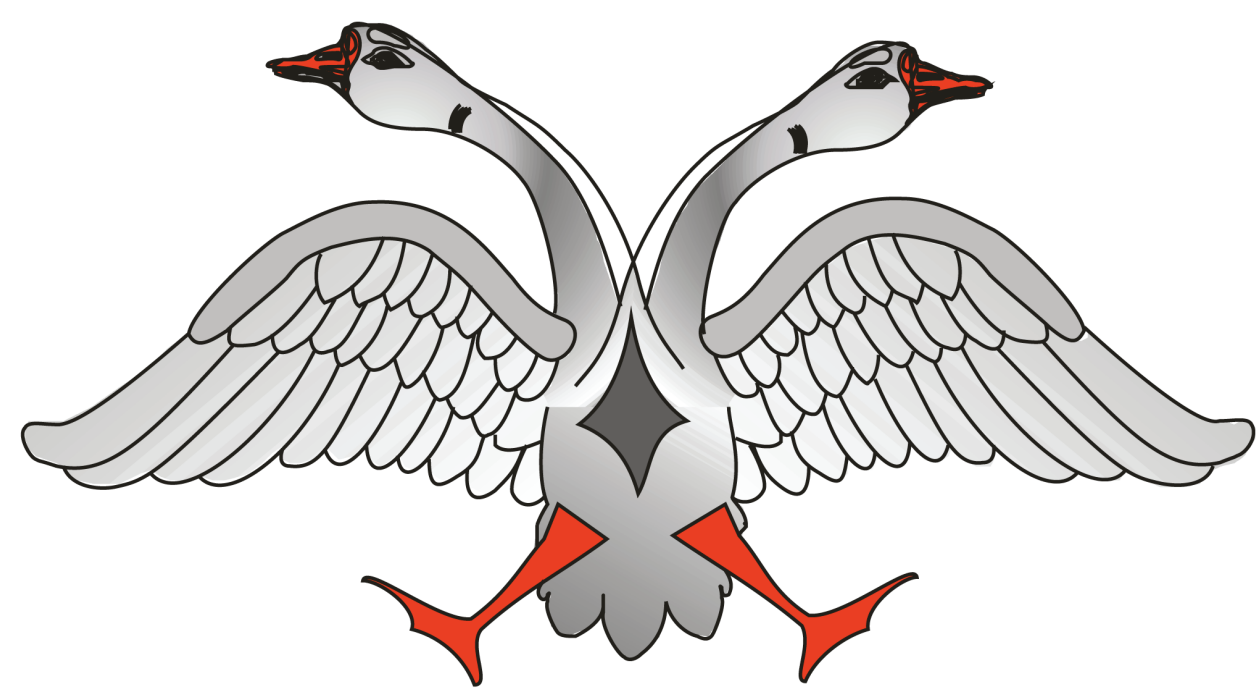

Figure 1. Logo of youth live shows in Shadrinsk, designed by Alexey Gushchin \& Eugene Serkov (from the private archive of A. Britvin). 
So, today the Shadrinsk goose is both an urban myth (as a reflection in the collective consciousness of the central position of the city in relation to the world) and an urban legend (as a genre of folklore in which historical events are represented in the form of symbolic generalization), and an example of a social construction with a reference to the past, to the former glory of the merchant city, as well as a guarantee for a prosperous future. So urban identity allows us to create a fusion of public consciousness and organically include a variety of symbolic elements in its composition.

Shadrinsk also has a more modern potential for symbolic capitalization. In our opinion, one of the most promising symbolic resources of Shadrinsk, which may be updated in the cultural space of Russia, is the legacy of sculptor Ivan Ivanov-Shadr (1887-1941), who was born in Shadrinsk and took the pseudonym "Shadr" accordingly. The sculptor's works became an integral part of the artistic images of socialist realism - from the sculpture "Cobblestone - the weapon of the proletariat" to the sculpture "The girl with an oar".

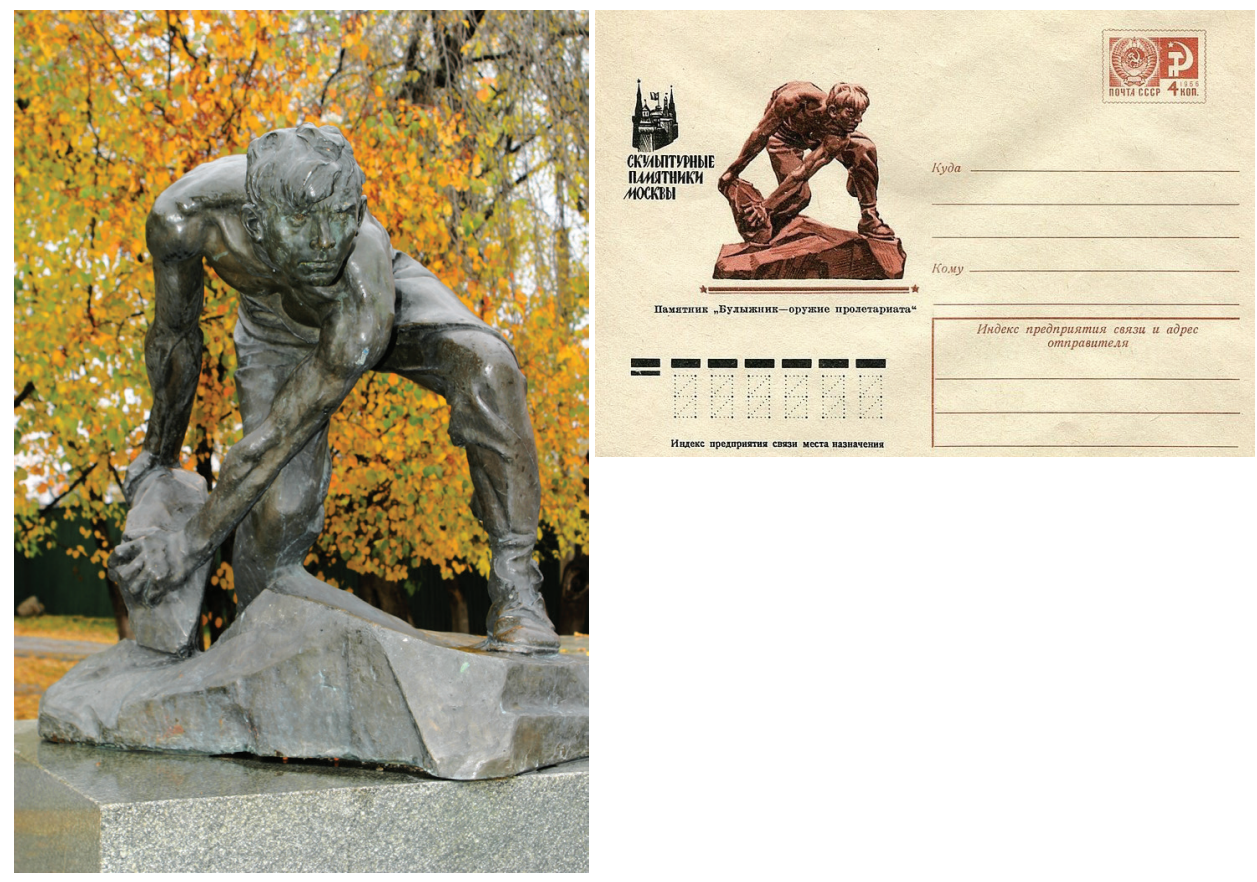

Figure 2. Left: Sculpture "Cobblestone - weapon of the proletariat" in Shadrinsk. Photograph by Vyacheslav Volynkin (2009). The original sculpture was installed in Moscow, in the Park of the December Uprising. Right: Postal envelope with the image of the sculpture. 
Sculptor Ivan Shadr is associated with Shadrinsk not only as a person born in the city, who used its name as a creative pseudonym: Shadrinsk peasants became the images of all the working people in his artworks, being embodied in the sculptures "The peasant" and "The sower". Pictured by engravers on the first Soviet currency and postage stamps, they represent the new Soviet state for the whole world. Shadrinsk peasants are depicted on the first Soviet banknotes, on the first gold coin of Soviet Russia, on the first postage stamps and even on packs of cigarettes. Other images created by I. Shadr - a worker and a Red Army soldier - are depicted on the first Soviet bonds of loans, payment obligations, and banknotes.

Below are some factors that favor the direction of converting the name and heritage of I. Shadr into the symbolic capital of Shadrinsk:

- The creative pseudonym, which has become a surname, is as close to the name of the city as possible and emphasizes the inextricable link between the sculptor and his homeland;

- Famous works of the sculptor ("Cobblestone - the weapon of the proletariat", "The girl with an oar", the first banknotes and stamps of the USSR, sculptural images of V. Lenin, gravestones and monuments to famous people, etc.);

- Recognition of the sculptor's name in Soviet art heritage;

- Inclusion of the biography and creative heritage of the sculptor into the political and artistic history of Russia;

- The geographical context of Shadr's life (Moscow, where most of the sculptor's works are located; St. Petersburg, where "The girl with an oar" is located; France, where Shadr studied under O. Rodin, E. Antoine Bourdelle, and A. Maillol).

We propose to use the sculpture "The girl with an oar" - one of the works of the sculptor still attracting wide attention - as an objectification of the image of I. Shadr. In June 2011, "The girl with an oar" was exhibited at the State Russian Museum as a symbol of the annual international regatta "Golden piers of St. Petersburg". Currently, copies of the sculpture have been installed both in Moscow and in St. Petersburg.

There is one more historical nuance which can enrich the heritage of I. Shadr as a symbolic resource for the promotion of the city of Shadrinsk. It is mistakenly believed that the sculpture of I. Shadr is a model for park gypsum copies, which were installed in many cities of the USSR. In fact, the work of sculptor Romuald Iodko with the same name was used as a sample for these park sculptures. It was the sculpture of a girl-athlete, not Shadr's original, which became the most common sculpture of the Soviet era and its symbol. Therefore, we also propose to develop a discourse of the unique and mass in the context of the narrative about the sculpture "The girl with an oar". 

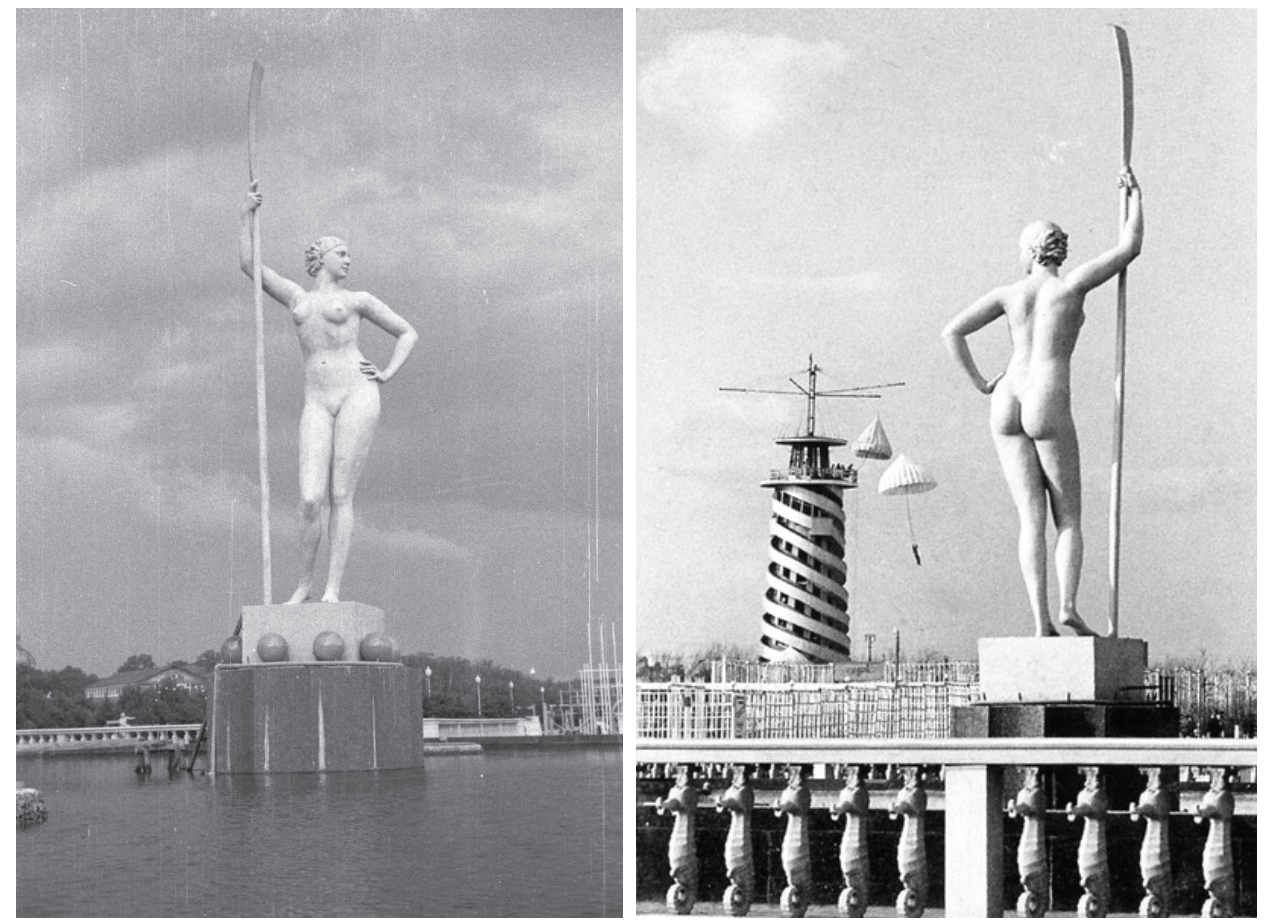

Figure 3. I. Shadr's sculpture "The girl with an oar" in Gorky Park in Moscow in the 1930s (destroyed by today). Left: Photograph by Harrison Forman, 1939 (from the University of Wisconsin-Milwaukee Libraries). Right: Photograph by Emmanuel Evzerihin, 1938 (from the private archive of E. Evzerikhin).

However, we can state that today the concept of the development and use of the symbolic capital in Shadrinsk is absent. Existing plans to promote trade and cultural brands should be summed up by a common strategy including both - the identifying of target audiences and choosing the communication channels. Officially declared in early 2010, the formula "Shadrinsk is the historical crossroads of trade routes" does not reflect the modern mission of the city. The geographical equidistance of the city from Yekaterinburg, Chelyabinsk, and Tyumen, placing Shadrinsk in the center, creates only an illusion of space, since it is not limited by either administrative or mental boundaries. In the sense of logistics, Shadrinsk has long been not a "four-port city": the main railway traffic goes through Tyumen, and the city does not benefit from the automobile transit of Yekaterinburg, Chelyabinsk, and Tyumen.

Nevertheless, one of our proposals has been accepted and developed. Today, Shadrinsk actively capitalizes the fairy-tale character Frog Princess. The Museum of the Frog Princess has been founded in Shadrinsk, with a concept presupposing the pyramidal construction of the narrative about the territory. 


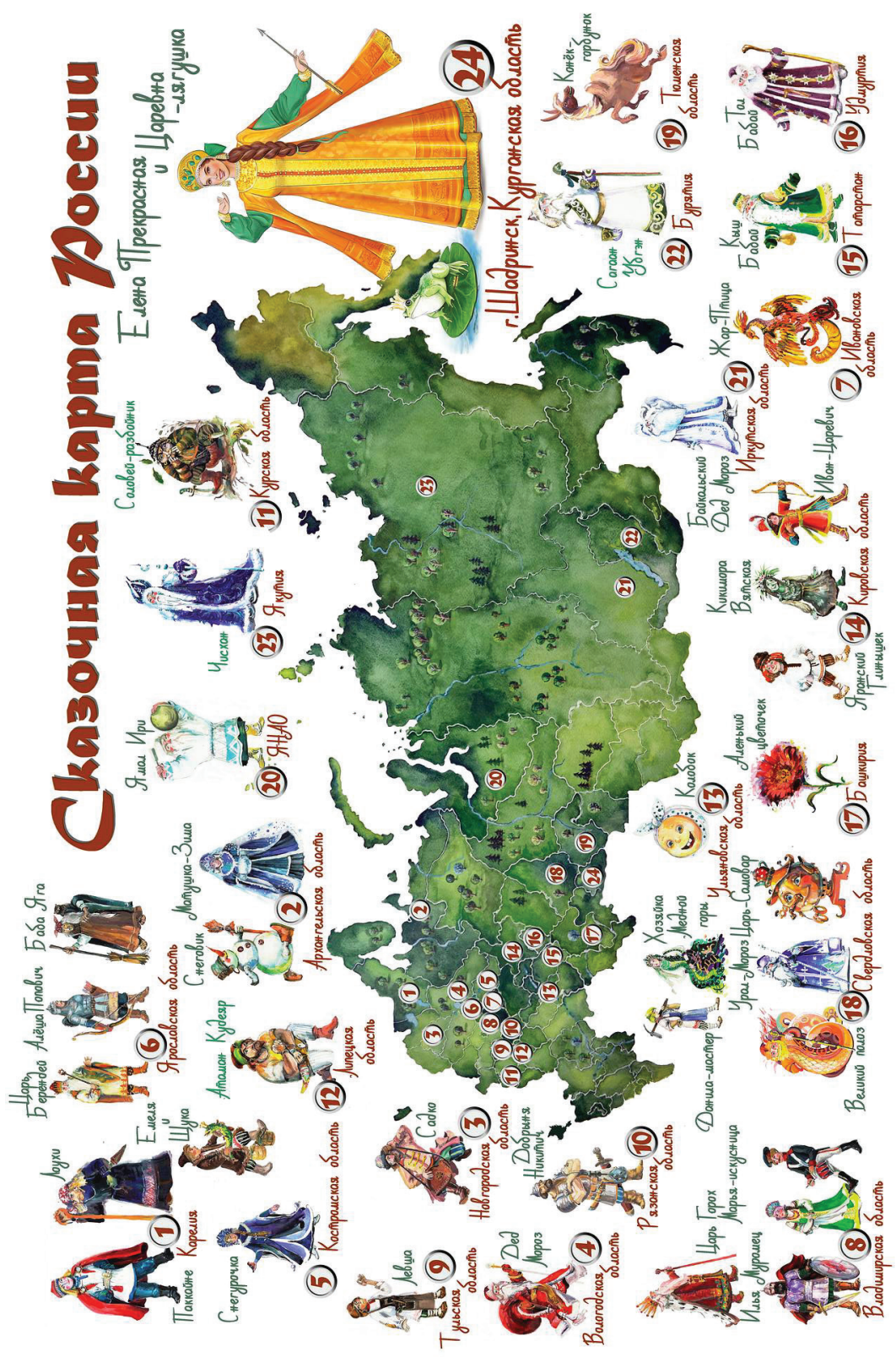

Figure 4. The whole fairytale map of Russia. No. 24 - "The Frog Princess and Elena the Beautiful". Available at https: / / www.facebook.com / fairytalemapofRussia, last accessed on 2 July 2020. 
The life, occupations, and local crafts of the peasants of the rich Shadrinsk district, the granary of the mining Urals, lie at the base of the concept. Russian verbal folk art (songs, tales, rites), reflecting people's worldview, constitutes the second level. And, finally, the Frog Princess herself, which works as a key to the understanding of the history as well as the future of Shadrinsk, affirming local values such as work and family.

In addition to the museum, the Frog Princess as a symbol of the city is objectified in the form of sculptural images and numerous souvenirs. But the main thing is the translation of the values of male and female cultures through festive and popular events. For this purpose, a special organization operates in the city. Moreover, the residence of Elena the Beautiful (the transfigured Frog Princess) was opened. As a result, it affected the activity of the mass media and, subsequently, the emergence of new excursion routes. This contributed to the inclusion of the city of Shadrinsk in the cultural and tourist project "Fairytale map of Russia" (Fig. 4), aimed at promoting Russian territories.

Thus, the formation of an umbrella territorial brand was initiated, allowing a free construction of narratives with the inclusion of identified symbolic resources, such as "The girl with an oar", "The Shadrinskiy goose", and male and female archetypes, which opens a wide scope for further interpretations of the cultural and historical heritage of this city.

\section{FINAL DISCUSSION AND CONCLUSIONS}

Many researchers have applied the concept of symbolic capital (Bourdieu 1980, 2002) to study the practices and capabilities of social actors that use it as a resource to achieve a certain social status, but just a few have worked on analyzing the symbolic resources of cities from place marketing or place branding perspectives (Hibbit 2017; Vizgalov 2011). Intangible heritage exerts great influence on the individual character of cities and is just the tip of the iceberg of their true identity, as many authors have discussed previously (e.g. Graham \& Howard 2008; Morgan \& Huertas 2011; San Eugenio Vela 2013; etc.). As a kind of symbolic capital of a territory, folklore and other kinds of intangible heritage can influence the way a place is trusted or distrusted by the residents and non-residents and, at the same time, could act as a powerful mental source when used for place promotion strategies (Schein 2004 [1985]; Zamiatin 2013).

To sum it all, we can conclude that the symbolic capital is the image of an object, expressing the idea of its high position in the hierarchy of a certain system of values. As a tool for promoting a territory, symbolic capital is the most mobile, plastic, and capable way of translation. For provincial cities that do not 
have significant economic and financial resources, the formation of symbolic capital is an important communication resource in increasing the attractiveness of provincial cities for both tourists and local residents. However, the formation of the symbolic capital is not a part of the branding strategy of the local authorities but rather remains the task of local ethnographers and enthusiasts only.

In Russia, there are still a few positive examples of the symbolic capital used in the development of tourist destinations or as an image component of the local identity of a provincial city: Veliky Ustyug ("Homeland of Ded Moroz/ Father Frost"), the city of Myshkin ("The city of museums"), Uryupinsk ("The capital of the Russian province"). However, many Russian cities have significant cultural resources, which, with rare exceptions, are neither reflected in their strategic development programs, nor included in their official communication strategies. The authors of the article gave examples of symbolic resources of three Russian provincial cities, showing the prospects of their capitalization. The successful promotion of these cities is related to the financial and organizational efforts of their municipal authorities. Initiatives of public organizations and individuals cannot lead to the desired effect of strengthening the branding of these territories.

\section{REFERENCES}

Aitken, Robert \& Campelo, Adriana 2011. The Four R's of Place Branding, Journal of Marketing Management, Vol. 27, No. 9-10, pp. 913-933. https://doi.org/10.1080 /0267257X.2011.560718.

Anholt, Simon 2009. Should Place Brands Be Simple? Place Branding and Public Diplomacy, Vol. 5, pp. 91-96. https://doi.org/10.1057/pb.2009.6.

Aronczyk, Melissa 2008. Living the Brand: Nationality, Globality, and the Identity Strategies of Nation Branding Consultants. International Journal of Communication, Vol. 2, pp. 41-65. Available at https://ijoc.org/index.php/ijoc/ article/view/218, last accessed on 15 June 2020.

Ashworth, Gregory J. 1994. From History to Heritage - From Heritage to Identity: In Search of Concepts and Models. In: G.J. Ashworth \& P.J. Larkham (eds.) Building a New Heritage: Tourism, Culture and Identity in the New Europe. London: Routledge, pp. 13-30.

Basaran, Tugba \& Olsson, Christian 2018. Becoming International: On Symbolic Capital, Conversion and Privilege. Millennium: Journal of International Studies, Vol. 46, No. 2, pp. 96-118. https://doi.org/10.1177\%2F0305829817739636.

Bauder, Harald \& Hannan, Charity-Ann \& Lujan, Omar 2017. International Experience in the Academic Field: Knowledge Production, Symbolic Capital, and Mobility Fetishism. Population, Space and Place, Vol. 23, No. 6, e2040. https://doi. org/10.1002/psp.2040. 
Baudrillard, Jean 1976. L'échange Symbolique et la Mort. Paris: Gallimard. Available at https://monoskop.org/File:Baudrillard_Jean_Lechange_symbolique_et_la_ mort_1976.pdf, last accessed on 15 June 2020.

Baudrillard, Jean 1988. Selected Writings. Edited by Mark Poster. Stanford: Stanford University Press.

Berger, Peter L. \& Luckmann, Thomas 1966. The Social Construction of Reality: A Treatise on Sociology of Knowledge. New York: Penguin Books.

Blumer, Herbert 1969. Symbolic Interactionism: Perspective and Method. Englewood Cliffs, NJ: Prentice-Hall.

Bourdieu, Pierre 1980. Le sens pratique. Paris: Minuit. Available at https://monoskop.org/ File:Bourdieu_Pierre_Le_sens_pratique_1980.pdf, last accessed on 15 June 2020.

Bourdieu, Pierre 2002. Formy kapitala. [Forms of Capital.] Ekonomicheskaia sotsiologiia [Journal of Economic Sociology], Vol. 3, No. 5, pp. 60-74. Available at https:// ecsoc.hse.ru/data/2011/12/08/1208205039/ecsoc_t3_n5.pdf\#page=60, last accessed on 15 June 2020.

Britvin, Alexey M. \& Britvina, Irina B. \& Starostova, Liudmila E. 2016. Integrativnaia model' brenda rossiiskogo goroda: regional'nyi aspekt. [Integrative Model of the Brand of the Russian City: The Regional Aspect.] Monograph. Ekaterinburg: Izdatel'stvo Ural'skogo universiteta. Available at http://elar.urfu.ru/ handle/10995/44104, last accessed on 15 June 2020.

Calvento, Mariana \& Colombo, Sandra Silvia 2009. La marca-ciudad como herramienta de promoción turística: ¿Instrumento de inserción nacional e internacional? [The City Brand as a Tourism Promotion Tool: A National and International Insertion Instrument?] Estudios y Perspectivas en Turismo, Vol. 18, No. 3, pp. 262-284. Available at https://www.estudiosenturismo.com.ar/PDF/V18/v18n3a2.pdf, last accessed on 15 June 2020.

Curtin, Patricia A. \& Gaither, T. Kenn 2007. International Public Relations: Negotiating Culture, Identity, and Power. Thousand Oaks \& London \& New Delhi: SAGE.

Dubeykovskiy 2017 = Dubeikovskii, Vasilii. Delai kak Uriupinsk: praktikum po razvitiiu provintsial'nogo goroda. [Do As Uryupinsk: A Workshop on the Development of the Provincial City.] Uryupinsk: City Branding.

Eliade, Mircea 1987 [1965]. Le Sacré et le Profane. [The Sacred and the Profane.] Paris: Gallimard. Available at https://monoskop.org/images/2/20/Eliade_Mircea_Le_ sacr\%C3\%A9_et_le_profane_1965.pdf, last accessed on 15 June 2020.

Gómez Schettini, Mariana \& Troncoso, Claudia Alejandra 2011. Tourism and Cultural Identity: Promoting Buenos Aires as the Cultural Capital of Latin America. Catalan Journal of Communication \& Cultural Studies, Vol. 3, No. 2, pp.195-209. https://doi.org/10.1386/cjcs.3.2.195_1.

Graham, Brian, \& Howard, Peter 2008. Heritage and Identity. In: Brian Graham \& Peter Howard (eds.) The Ashgate Research Companion to Heritage and Identity. Aldershot \& Burlington: Ashgate, pp. 1-15.

Grignoli, Daniela \& Mancini, Antonio 2016. Un territorio para el desarrollo. [A Territory for Development.] PAMPA, Vol. 13, pp. 77-96. Available at https://dialnet. unirioja.es/servlet/articulo?codigo $=5610765$, last accessed on 15 June 2020.

GSE 1977 = Bol'shaia sovetskaia entsiklopediia . [Great Soviet Encyclopedia.] Moscow: Sovetskaia Entsiklopediia, Vol. 27, p. 63. 
GSE 1978 = Bol'shaia sovetskaia entsiklopediia . [Great Soviet Encyclopedia.] Moscow: Sovetskaia Entsiklopediia, Vol. 29, p. 273.

Guenon, René 1962. Symboles de la Science Sacrée. [Symbols of Sacred Science.] Paris: Gallimard. Available at http://classiques.uqac.ca/classiques/guenon_rene/ Symboles_science_sacree/symboles_sc_sacree.html, last accessed on 15 June 2020.

Hall, Colin Michael 2010. Tourism Destination Branding and Its Effects on National Branding Strategies: Brand New Zealand, Clean and Green But Is It Smart? European Journal of Tourism, Hospitality and Recreation, Vol. 1, No. 1, pp. 68-89. Available at https://www.researchgate.net/publication/277201118, last accessed on 15 June 2020.

Hibbitt, Richard 2017. Bruges as Symbolic Capital. Forum for Modern Language Studies, Vol. 53, No. 3, pp. 349-359. https://doi.org/10.1093/fmls/cqx012.

Hildreth, Jeremy 2010. Place Branding: A View at Arm's Length. Place Branding and Public Diplomacy, Vol. 6, No. 1, pp. 27-35. Available at https://www.academia. edu/11481657/, last accessed on 15 June 2020.

Kavaratzis, Mihalis 2004. From City Marketing to City Branding: Towards a Theoretical Framework for Developing City Brands. Place Branding, Vol. 1, No. 1, pp. 58-73. http://dx.doi.org/10.1057/palgrave.pb.5990005.

Kotler, Philip \& Haider, Donald H. \& Rein, Irving 1993. Marketing Places: Attracting Investment, Industry, and Tourism to Cities, States, and Nations. New York: The Free Press.

Locock, Louise \& Boylan, Anne-Marie \& Snow, Rosamund \& Staniszewska, Sophie 2017. The Power of Symbolic Capital in Patient and Public Involvement in Health Research. Health Expectations, Vol. 20, No. 5, pp. 836-844. https://dx.doi. org/10.1111\%2Fhex.12519.

Losev, Aleksei 1994. Mif. Chislo. Sushchnost'. [Myth. Number. Essence.] Moscow: Mysl'. Lotman, Juri 2010 [2000]. Semiosfera: Kul'tura i vzryv. Vnutri mysliashchikh mirov: Stat'i. Issledovaniia. Zametki. [The Semiosphere: Culture and Explosion. Inside the Thinking Worlds: Articles. Research. Notes.] St. Petersburg: Iskusstvo-SPB.

Michelson, Aleksandr \& Paadam, Katrin 2016. Destination Branding and Reconstructing Symbolic Capital of Urban Heritage: A Spatially Informed Observational Analysis in Medieval Towns. Journal of Destination Marketing and Management, Vol. 5, No. 2, pp. 141-153. https://doi.org/10.1016/j.jdmm.2015.12.002.

Mihailovich, Philippe 2006. Kinship Branding: A Concept of Holism and Evolution for the Nation Brand. Place Branding, Vol. 2, pp. 229-247. https://doi.org/10.1057/ palgrave.pb.5990060.

Morgan, Nigel \& Huertas, Assumpció 2011. Advancing the Study of Place Brands, Tourism and Reputation Management. Catalan Journal of Communication \& Cultural Studies, Vol. 3, No. 2, pp. 149-158. https://doi.org/10.1386/cjcs.3.2.149_2.

Palmer, Catherine 1999. Tourism and the Symbols of Identity. Tourism Management, Vol. 20, No. 3, pp. 313-321. https://doi.org/10.1016/S0261-5177(98)00120-4.

Peterková, Jana 2003. European Cultural Identity: The Role of Cultural Heritage in the Process of Mutual Communication and Creation of Consciousness of Common Cultural Identity. Kakanien Revisited, Vol. 20, No. 8, pp. 1-5. Available at http:// www.kakanien-revisited.at/beitr/fallstudie/JPeterkova1.pdf, last accessed on 16 June 2020. 
Radaev, Vadim 2002. Poniatie kapitala, formy kapitalov i ikh konvertatsiia. [Concept of Capital, Forms of Capitals, and Their Conversion.] Ekonomicheskaia sotsiologiia [Journal of Economic Sociology], Vol, 3, No. 4, pp. 20-32. Available at https:// ecsoc.hse.ru/2002-3-4/annot.html\#doc_26593609, last accessed on 16 June 2020.

San Eugenio Vela, Jordi de 2013. Fundamentos conceptuales y teóricos para marcas de territorio. [Conceptual and Theoretical Foundations for Place Brands.] Boletín de la Asociación de Geógrafos Españoles, Vol. 62, pp. 189-212. https://doi. org/10.21138/bage.1575.

San Eugenio Vela, Jordi de \& Xifra, Jordi 2014. International Representation Strategies for Stateless Nations: The Case of Catalonia's Cultural Diplomacy. Place Branding and Public Diplomacy, Vol. 11, No. 1, pp. 83-96. https://doi.org/10.1057/ pb.2014.17.

Schein, Edgar H. 2004 [1985]. Organizational Culture and Leadership. 3rd ed. San Francisco: Jossey-Bass.

Skinner, Heather 2008. The Emergence and Development of Place Marketing's Confused Identity. Journal of Marketing Management, Vol. 24, No. 9-10, pp. 915-928. https://doi.org/10.1362/026725708X381966.

Smith, Laurajane 2006. Uses of Heritage. Abingdon, UK: Routledge.

Vandyshev, Mikhail \& Veselkova, Natalia \& Priamikova, Elena 2013. Mesta pamiati i simvolicheskii kapital territorii v mental'nykh kartakh gorozhan. [Places of Memory and the Symbolic Capital of Territories in the Mental Maps of Citizens.] Zhurnal sotsiologii $i$ sotsial'noi antropologii [The Journal of Sociology and Social Anthropology], Vol. 16, No. 3, pp. 101-111. Available at http://www.jourssa. $\mathrm{ru} / \mathrm{q}=\mathrm{ru} / 2013 \_3$, last accessed on 16 June 2020.

Vizgalov, Denis 2011. Brending goroda. [City Branding.] Moscow: Institut ekonomiki goroda. Available at http://www.urbaneconomics.ru/sites/default/files/3467_ import.pdf, last accessed on 16 June 2020.

Vizgalov, Denis 2015. Pust' goroda zhivut. [Let the Cities Live.] Moscow: Sektor.

Yamak, Sibel \& Ergur, Ali \& Özbilgin, Mustafa F. \& Alakavuklar, Ozan Nadir 2016. Gender as Symbolic Capital and Violence: The Case of Corporate Elites in Turkey. Gender, Work and Organization, Vol. 23, No. 2, pp. 125-146. https:// doi.org/10.1111/gwao.12115.

Zamiatin, Dmitry 2013. Geokul'turnyi brending territorii: kontseptual'nye osnovy. [Geocultural Branding of Territories: The Conceptual Grounds.] Labirint: zhurnal sotsial'no-gumanitarnykh issledovanii [Labyrinth: Journal of Philosophy and Social Sciences], Vol. 5, pp. 11-23. Available at http://journal-labirint.com/wpcontent/uploads/2013/12/zamyatin.pdf, last accessed on 16 June 2020.

Zamiatin, Dmitry \& Zamiatina, Nadezhda \& Mitin, Ivan 2008. Modelirovanie obrazov istoriko-kul'turnoi territorii: metodologicheskie $i$ teoreticheskie podkhody. [Modeling the Images of Historical and Cultural Territory: Methodological and Theoretical Approaches.] Moscow: Institut naslediia. 
Alexey Britvin is Lecturer at the Chair of Integrated Marketing Communications and Branding at the Institute of Administration and Entrepreneurship, School of Economics and Management, Ural Federal University (Yekaterinburg, Russia). He was the organizer of conferences on the branding of small and medium-sized cities of Russia from 2011 to 2015 . His research interests cover the symbolic capital of territories and historical and cultural heritage.

alexey.britvin@urfu.ru

Irina Britvina is Doctor of Sociology, Professor at the Chair of Integrated Marketing Communications and Branding at the Institute of Administration and Entrepreneurship, School of Economics and Management, Ural Federal University (Yekaterinburg, Russia). In 1994-1995 she participated in the description of budgets of rural families of the Ural region under the supervision of Doctor T. Shanin (Great Britain). Then she worked on the last stages of the international project "Ways of generation" under the supervision of Doctor M. Titma (Estonia). Having received an individual grant of McArtur Fund (Chicago, USA) in 2002, she was deeply engaged in the studies of the adaptation of the compelled migrants in the conditions of a typical Russian city. Her research interests include sociology of culture and sociology of migration.

irina.britvina@urfu.ru

Liudmila Starostova is Associate Professor of Philosophy (PhD) at the Chair of Integrated Marketing Communications and Branding at the Institute of Administration and Entrepreneurship, School of Economics and Management, Ural Federal University (Yekaterinburg, Russia). Her sphere of scientific interests includes the social history of avant-garde architecture, architecture, and urban planning policy of modernism in the 20th century as a symbolic resource of place branding in the Urals. She co-organized conferences on the branding of small and medium-sized cities of Russia from 2011 to 2014, and was the curator of the exhibition project "Days of Constructivism in the Urals" in 2016, 2017, and 2019.

starostova5@mail.ru

Marc Compte-Pujol is Doctor of Communication and Lecturer at the Faculty of Business and Communication, University of Vic - Central University of Catalonia (Vic, Barcelona, Spain). He is member of the research group "Learning, Media \& Social Interactions" (2017SGR379). His research interests cover place branding, heritage communication, and public relations.

marc.compte@uvic.cat 